\title{
Farm Efficiency Measure Analysis of Tea Plantation Crop in Mokokchung District of Nagaland, India
}

\author{
Imlibenla and Amod Sharma* \\ Department of Agricultural Economics, SASRD, Nagaland University, \\ Medziphema Campus, Nagaland, India \\ *Corresponding author
}

\begin{tabular}{|l|}
\hline Ke y w o r d s \\
Plantation, Tea, \\
Economic, Farm, \\
Small, Medium, \\
Large
\end{tabular}

\section{A B S T R A C T}

A study was conducted to analyze the economics of different tea plantation farms in Mokokchung district of Nagaland state, both primary and secondary data were used. The primary data pertained to the year 2018-19 and was elicited from 90 tea plantation cultivators and 10 market intermediaries were also selected for the data collection through pre-tested questionnaires. Total cost of tea production for small farm size category was accounted to be Rs 34627.20/-, out of which total variable cost was Rs 24734.80/- and total fixed cost was Rs 9402.40/-. The highest cost was incurred on hired human labour, constituting 39.20 per cent of the total cost. In the medium farm size category, the variable cost was Rs 79661.30/- and fixed cost (Rs 28852.60/-) of the total cost which was Rs 108813.90/-. The highest cost was incurred on hired human labour constituting 59.30 per cent of the total cost. In the large farm size category, the total cost for tea production was accounted to be Rs 259440.50/-, out of which total variable cost was Rs 190595.60/- and total fixed cost was Rs 35583.30/-. The highest cost was incurred on hired human labor constituting 64.90 per cent of the total cost in the small farm size group, respectively. For large farm size category, the overall gross farm income was estimated to be Rs 577556 and the net return excluding and including family labor were Rs 386960.40/- and Rs 396295.70/-, respectively. The farm business income was estimated to be Rs 372134.90/and farm labor income was Rs 371784.90/-. The net farm income was Rs 362449.60/-. The benefit cost ratio was estimated to be 2.20 , respectively.

\section{Introduction}

Tea is one of the world's most consumed beverages and it is known as the "Queen of Beverages". It is India's one of the most important plantation crops due to its eminent earning position in foreign exchange and its contribution to country's GNP. India has the world's largest area under tea and is the third largest exporter next to China and Kenya contributing about $11 \%$ of the world's total exports (Tea Export Report 2018). The production of tea in India for the year 2018 stood at 1325.05 million $\mathrm{kgs}$ and the total exports was 256.57 million kgs (Assessment of the Indian Tea Industry 2018).

The tea industry in India is about 172 years old and it is perhaps one of the only industries which has maintained its leadership in terms 
of production over the past 150 years. Indian tea is among the finest in the world owing to strong geographical indications, heavy investments in tea processing units, continuous innovation, augmented product mix and strategic market expansion (Tea Board of India, 2018).

India is the second largest producer of tea in the world after China. The country is home to a wide variety of teas including CTC tea, orthodox tea, green tea and organic tea. Unlike many other tea producing and exporting nations, India has a manufacturing base for both CTC and orthodox tea, in addition to green tea. India offers high quality specialty teas, such as Darjeeling, Assam Orthodox and high-range Nilgiri tea, which have a distinct aroma, strength, color and flavor (Tea Board of India, 2018).

Nagaland is a state in North East India. It borders the state of Assam to the west, Arunachal Pradesh and Assam to the north, Myanmar to the east and Manipur to the south. It has an area of $16,579 \mathrm{sq} . \mathrm{km}$ and the total cultivable area is 721,924 hectare (Nagaland Basic Facts 2016). About 70.00 per cent of the population depends on rural cultivation; the main crops are rice, millet, maize and pulses; about $80 \%$ of the cropped area is dedicated to rice; tea, coffee, rubber and cardamom are the main plantation crops grown in Nagaland (World Food India, 2017).

According to Statistical Handbook of Nagaland 2017, the area under tea stands at 7600 ha and total production accounts for 33900 metric tonnes. Nagaland tea is akin to Darjeeling tea in terms of brew and flavor (The Telegraph October 15, 2002).

\section{Materials and Methods}

Mokokchung is a district of Nagaland state in India which is mainly occupied by the Ao
Naga tribe. Its headquarters is Mokokchung town. This district covers an area of about $1615 \mathrm{sq} \mathrm{km}$ and is bounded by the state of Assam to its north, Wokha district to its west, Tuensang and Longleng district to its east, and Zunheboto district to its south.

The selection of villages was done purposively based on the availability of tea growers. From Tuli sub-division, 6 villages were selected namely Anike, Wamaken, Merangkong, Kangtsung, Anakiyimsen and Wamakenyimsen. From each village, the list of farmers who were growing tea for the past 5-6 years obtained, from which 15 farmers were randomly selected so that there will be uniformity in their yield. Thus, altogether the total number of respondents was 90. The selected respondents were then categorized into three groups namely small, marginal and large based on their area of tea gardens. Due to wide variation amongst the area under tea garden, the categorization was done by adding and subtracting the average and standard deviation of the respondent's tea areas. The categorization viz; (i). Small farm- up to 0.70 ha, Medium farm - 0.71 to 3.20 ha and Large farm -3.21 ha and above, respectively.

\section{Results and Discussion}

In order to assess the profitability of tea farm enterprise, cost and return analysis was done. However, the study emphasized on one year analysis of established tea gardens. Therefore, cost concerning initial seedling costs and land preparation activities were neglected (Choudhary et al., 2017).

Table 1 reveals that the cost of tea production for different categories of sampled farmers. Pooled data revealed that hired human labor accounted for the highest share which was 30.70 per cent of the total cost, followed by owned labour (3.40 per cent). The total cost accounted for tea production in a year was 
estimated to be Rs 267987.80/- of which variable cost was Rs 98410.60/- and fixed cost (Rs 35583.30/-). Pooled data revealed that the remaining items does not contribute much to the total variable cost which includes fertilizer expense $(1.30$ per cent $)$, miscellaneous ( 0.80 per cent), planting materials for gap filling ( 0.40 per cent) and plant protection materials ( 0.20 per cent). The data reveals that expenditure on fertilizers are comparatively less due to the fact that the soils used for tea cultivation are virgin soils and hence at present soil fertility is not a serious issue in the study area. The fixed cost analysis revealed that depreciation constituted 0.70 per cent of the total cost, imputed rental value on owned land (12.50 per cent) and interest on value of owned fixed capital assets (0.10 per cent), respectively.

In the first category i. e; small farmers, the total cost for tea production was accounted to be Rs 34627.20/-, out of which total variable cost was Rs 24734.80/- and total fixed cost was Rs 9402.40/-. The highest cost was incurred on hired human labour constituting 39.20 per cent of the total cost, followed by owned labour expense (25.40 per cent). In case of variable cost, the third higest expenditure was incurred on fertilizers (3.04 per cent), followed by cost of planting materials for gap filling (1.40 per cent), miscellaneous (1.40 per cent) and plant protection materials (1.04 per cent). The fixed cost analysis revealed that the cost incurred on depreciation was 3.50 per cent of the total cost, imputed rental value of owned land (22.94 per cent) and interest on value of owned fixed capital assets ( 0.70 per cent), respectively.

In the second category i. e; medium farmers, the variable cost was Rs 79661.30/- and fixed cost (Rs 28852.60/-) of the total cost which was Rs 108813.90/-. In case of variable cost, the highest cost was incurred on hired human labour constituting 59.30 per cent of the total cost, followed by owned labour (8.40 per cent), fertilizers (3.04 per cent), planting materials for gap filling (2.06 per cent), miscellaneous (1.50 per cent) and plant protection materials (1.04 per cent). The fixed cost analysis revealed that the cost incurred on depreciation was 3.50 per cent of the total cost, imputed rental value of owned land (22.94 per cent) and interest on value of owned fixed capital assets ( 0.80 per cent), respectively.

In the third category i. e; large farmers, the total cost for tea production was accounted to be Rs $259440.50 /-$, out of which total variable cost was Rs 190595.60/- and total fixed cost was Rs 35583.30/-. The highest cost was incurred on hired human labor constituting 64.90 per cent of the total cost. In case of variable cost, owned labour accounted for 3.60 per cent of the total cost, fertilizers $(2.40$ per cent), planting materials for gap filling ( 0.50 per cent), miscellaneous ( 1.60 per cent) and plant protection materials (1.04 per cent). The fixed cost analysis revealed that the cost incurred on depreciation was 3.50 per cent of the total cost, imputed rental value of owned land (22.94 per cent) and interest on value of owned fixed capital assets ( 0.80 per cent), respectively (Sharma et al., 2000).

Thus, it can be said that as farm size increases, expenditure on all inputs increases and vice versa. Similar findings was obtained by Sharma et al., 2016, in which intergroup analysis was done for five categories of farms size in Assam and revealed that larger size group spent more on all items, showing increased use of all the components with increase in farm size.

Farm efficiency measures helps in identifying those farm enterprises which are performing against farm expectations and thus, helps in taking positive measures to overcome and 
strengthen the profitability of the enterprise. To know the efficiency of tea plantation practiced by the respondents, farm efficiency measures was applied. Based on the obtained data, gross farm income, net return including and excluding family labors, farm business income, farm labor income and net farm income were calculated for the three categories of the sampled respondents. Accordingly, benefit cost ratios were obtained (Sharma, 2011).
On an average basis, the overall gross farm income was estimated to be Rs 287775.50/and the net return excluding and including family labor were Rs189444.90/- and Rs 199331.50/- respectively. The farm business income was estimated to be Rs 186067.4 and farm labor income was Rs 185767.40/-. The overall net farm income was Rs 176661.80/-. The overall benefit cost ratio was estimated to be 1.07 (Vengoto, 2018) (Fig. 1-7).

Table.1 Cost of tea production for different categories of farms for the year 2018 (in Rs)

\begin{tabular}{|c|c|c|c|c|}
\hline \multirow[t]{2}{*}{ Particulars } & \multicolumn{4}{|c|}{ Farm category } \\
\hline & Small & Medium & Large & Overall \\
\hline \multicolumn{5}{|l|}{ A. Variable cost } \\
\hline $\begin{array}{l}\text { 1. Cost of planting materials(gap } \\
\text { filling) }\end{array}$ & $\begin{array}{r}473.33 \\
(1.40)\end{array}$ & $\begin{array}{c}1047.40 \\
(0.96)\end{array}$ & $\begin{array}{c}1252.94 \\
(0.50)\end{array}$ & $\begin{array}{c}1004.60 \\
(0.40)\end{array}$ \\
\hline 2. Cost of plant protection & $\begin{array}{c}359.50 \\
(1.03)\end{array}$ & $\begin{array}{l}513.10 \\
(0.50)\end{array}$ & $\begin{array}{c}1099.60 \\
(0.40)\end{array}$ & $\begin{array}{l}657.40 \\
(0.20)\end{array}$ \\
\hline 3.Cost of fertilizers & $\begin{array}{c}1052.00 \\
(3.04)\end{array}$ & $\begin{array}{c}2703.50 \\
(2.50)\end{array}$ & $\begin{array}{c}6337.12 \\
(2.40)\end{array}$ & $\begin{array}{c}3364.20 \\
(1.30)\end{array}$ \\
\hline \multicolumn{5}{|l|}{ 4. Labor expense } \\
\hline a. Owned & $\begin{array}{l}8790.00 \\
(25.40)\end{array}$ & $\begin{array}{c}9191.40 \\
(8.40)\end{array}$ & $\begin{array}{c}9335.30 \\
(3.60)\end{array}$ & $\begin{array}{c}9105.60 \\
(3.40)\end{array}$ \\
\hline b. Hired & $\begin{array}{c}13560.00 \\
(39.20)\end{array}$ & $\begin{array}{c}64507.80 \\
(59.30)\end{array}$ & $\begin{array}{c}168423.50 \\
(64.90)\end{array}$ & $\begin{array}{c}82163.80 \\
(30.70)\end{array}$ \\
\hline 5. Miscellaneous & $\begin{array}{c}500.00 \\
(1.40)\end{array}$ & $\begin{array}{c}1698.30 \\
(1.60)\end{array}$ & $\begin{array}{c}4147.10 \\
(1.60)\end{array}$ & $\begin{array}{c}2115.20 \\
(0.80)\end{array}$ \\
\hline Total variable cost & 24734.80 & 79661.30 & 190595.60 & 98410.60 \\
\hline \multicolumn{5}{|l|}{ B. Fixed cost } \\
\hline 1. Depreciation & $\begin{array}{c}1208.00 \\
(3.50)\end{array}$ & $\begin{array}{c}1710.60 \\
(1.60)\end{array}$ & $\begin{array}{c}2409.70 \\
(0.90)\end{array}$ & $\begin{array}{c}1776.10 \\
(0.70)\end{array}$ \\
\hline $\begin{array}{l}\text { 2. Imputed rental value of owned } \\
\text { land }\end{array}$ & $\begin{array}{c}7944.40 \\
(22.94)\end{array}$ & $\begin{array}{c}26841.95 \\
(24.70)\end{array}$ & $\begin{array}{c}65735.30 \\
(25.30)\end{array}$ & $\begin{array}{c}33507.20 \\
(12.50)\end{array}$ \\
\hline $\begin{array}{l}\text { 3. Interest on value of owned fixed } \\
\text { capital assets excluding land }\end{array}$ & $\begin{array}{r}250.00 \\
(0.70)\end{array}$ & $\begin{array}{c}300.00 \\
(0.30)\end{array}$ & $\begin{array}{l}350.00 \\
(0.10)\end{array}$ & $\begin{array}{c}300.00 \\
(0.10)\end{array}$ \\
\hline Total Fixed Cost & 9402.40 & 28852.60 & 68494.90 & 35583.30 \\
\hline Total cost & $\begin{array}{c}34627.20 \\
(100.00)\end{array}$ & $\begin{array}{c}108813.90 \\
(100.00)\end{array}$ & $\begin{array}{c}259440.50 \\
(100.00)\end{array}$ & $\begin{array}{c}267987.80 \\
(100.00)\end{array}$ \\
\hline
\end{tabular}

(Figures in parenthesis indicate percentage to total cost) 
Table.2 Return from tea production for different categories of sample farms

\begin{tabular}{|c|l|c|c|c|c|}
\hline SN & \multicolumn{1}{|c|}{ Particulars } & Small & Medium & Large & Overall \\
\hline 1. & Gross farm income & 58688.53 & 227081.90 & 577556.00 & 287775.50 \\
\hline 2. & Net return including family labor & 33953.73 & 147420.60 & 386960.40 & 189444.90 \\
\hline 3. & Net return excluding family labor & 45086.93 & 156611.90 & 396295.70 & 199331.50 \\
\hline 4. & Farm business income & 39622.36 & 146444.90 & 372134.90 & 186067.40 \\
\hline 5. & Family labor income & 39372.36 & 146144.90 & 371784.90 & 185767.40 \\
\hline 6. & Net farm income & 30582.36 & 136953.50 & 362449.60 & 176661.80 \\
\hline 7. & Benefit cost ratio & 1.695 & 2.087 & 2.226 & 1.074 \\
\hline
\end{tabular}

Fig.1 Area of land use under tea plantation

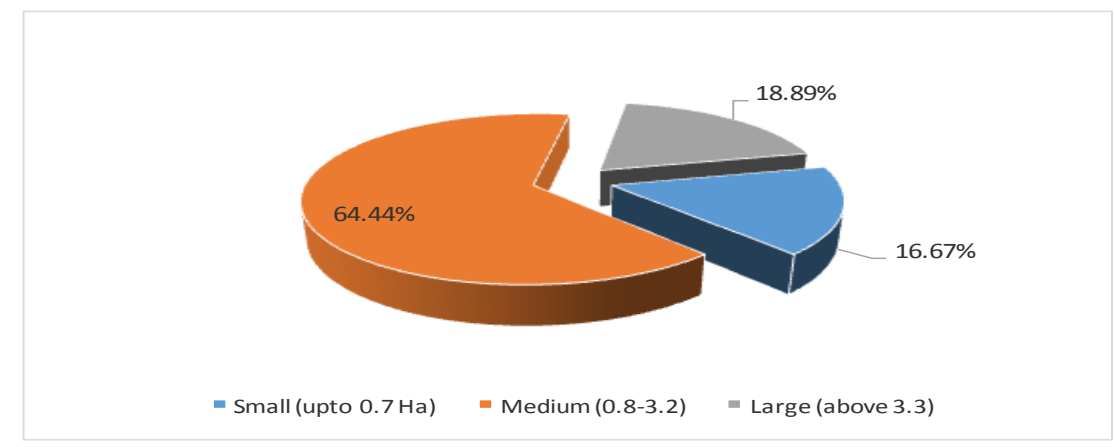

Fig.2 Flow chart of sampling design

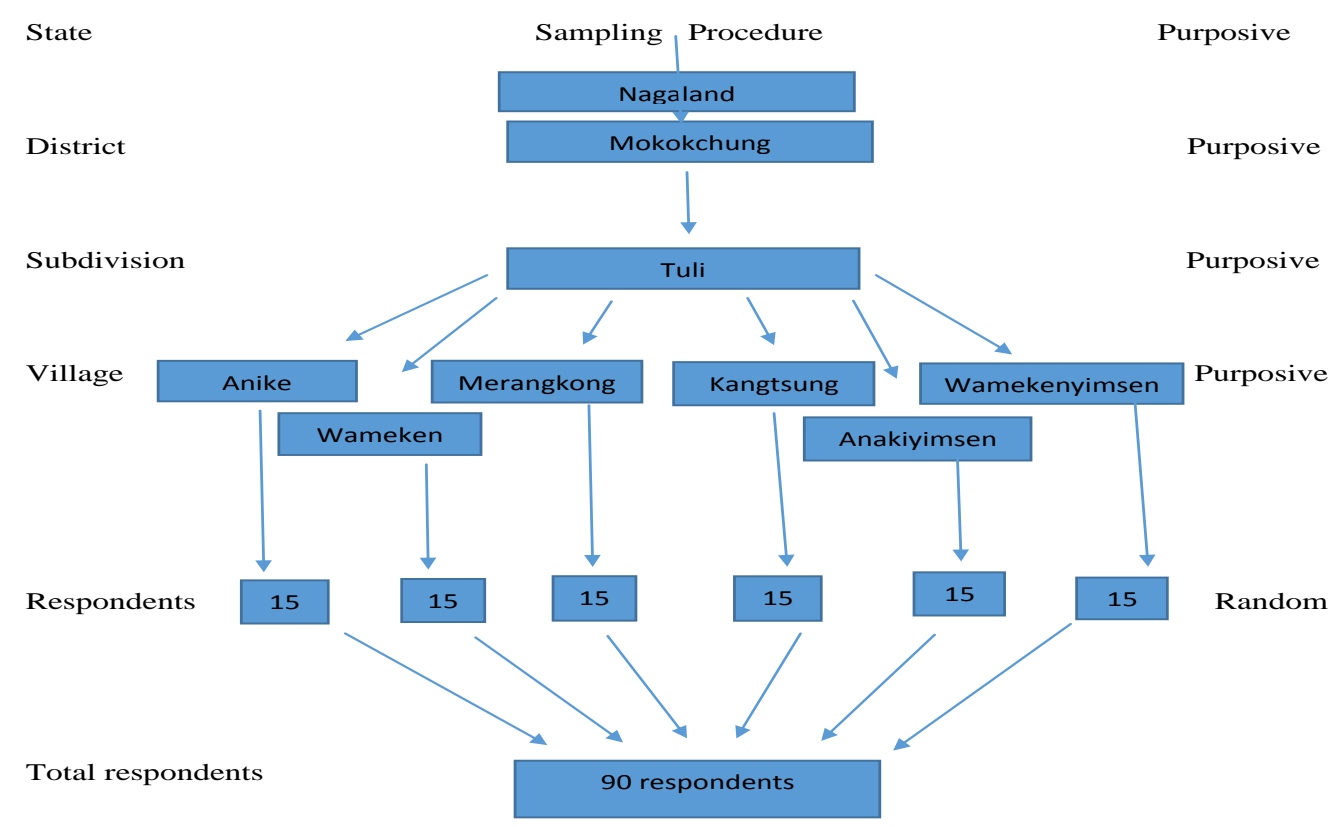


Fig.3 Cost of tea production on different farm size groups

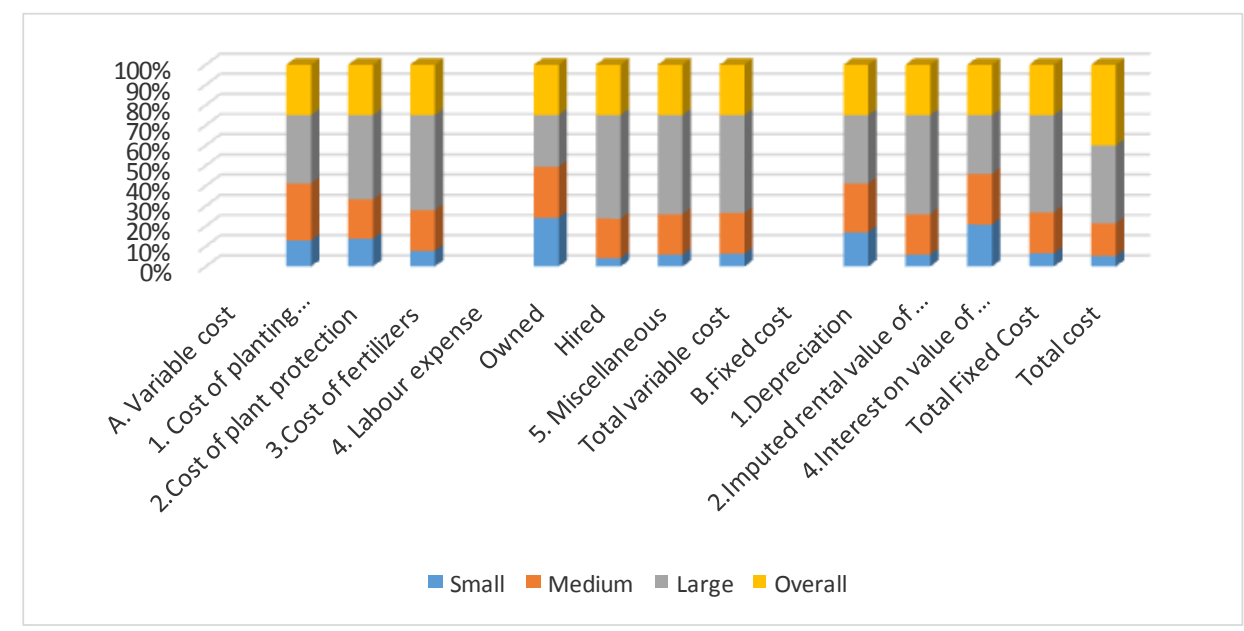

Fig.4 Cost of tea production for small farms

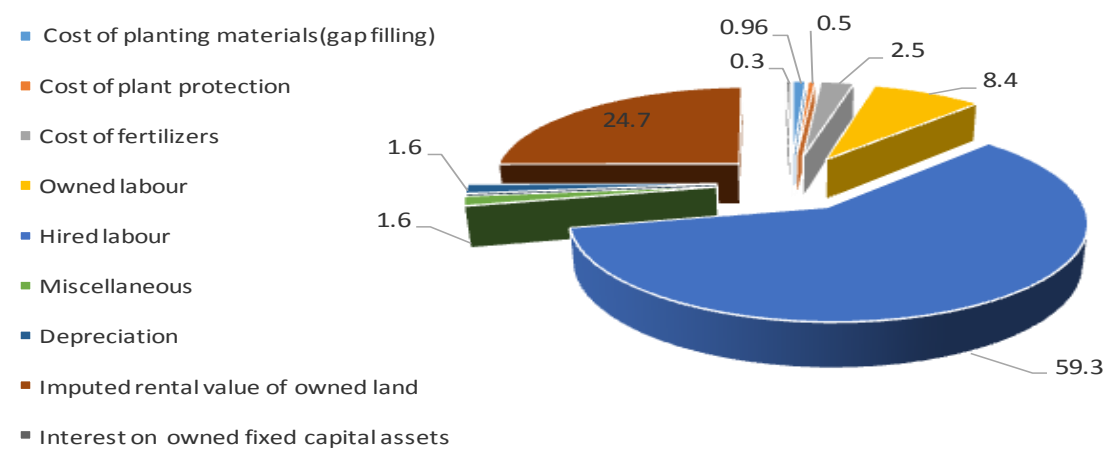

Fig.5 Cost of tea production for large farms

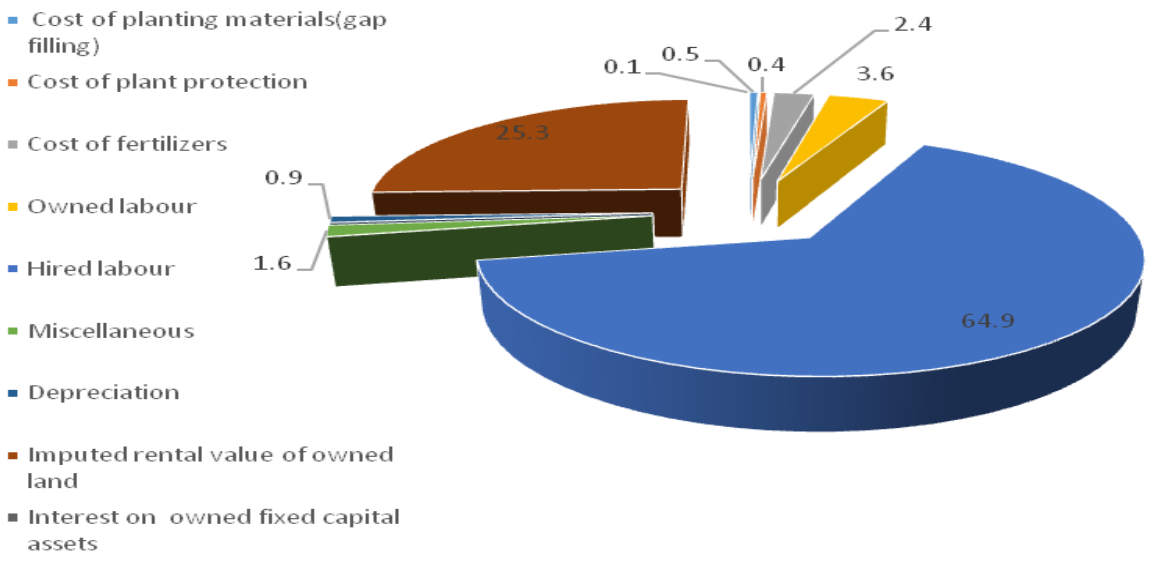


Fig.6 Cost of tea production for overall farms

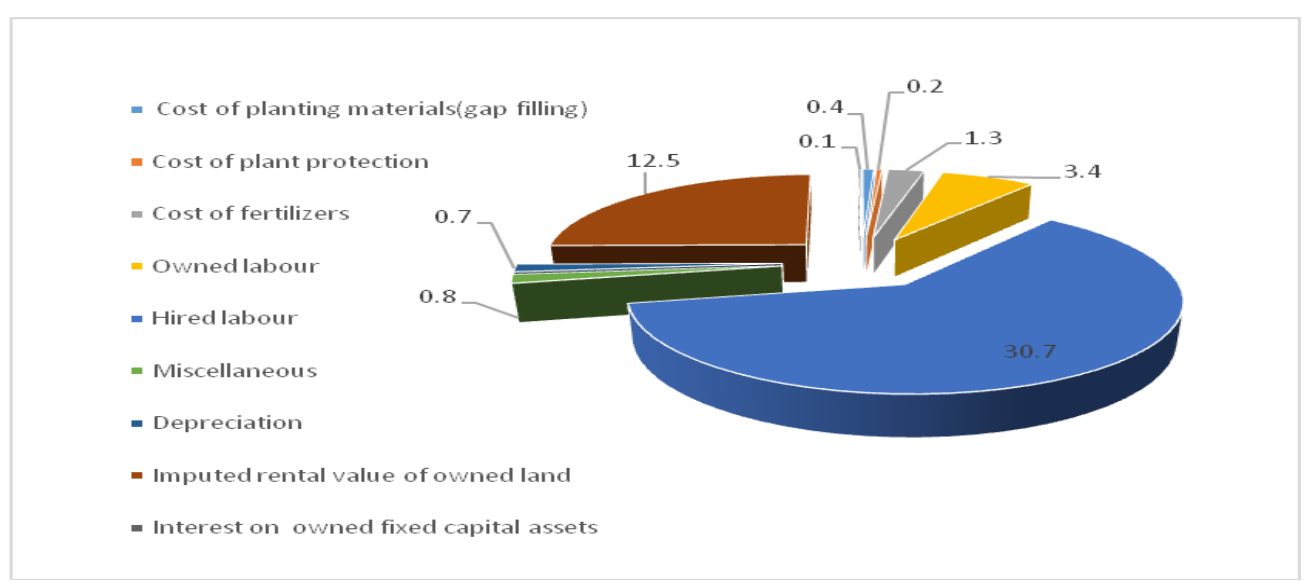

Fig.7 Return analysis on different farm size group

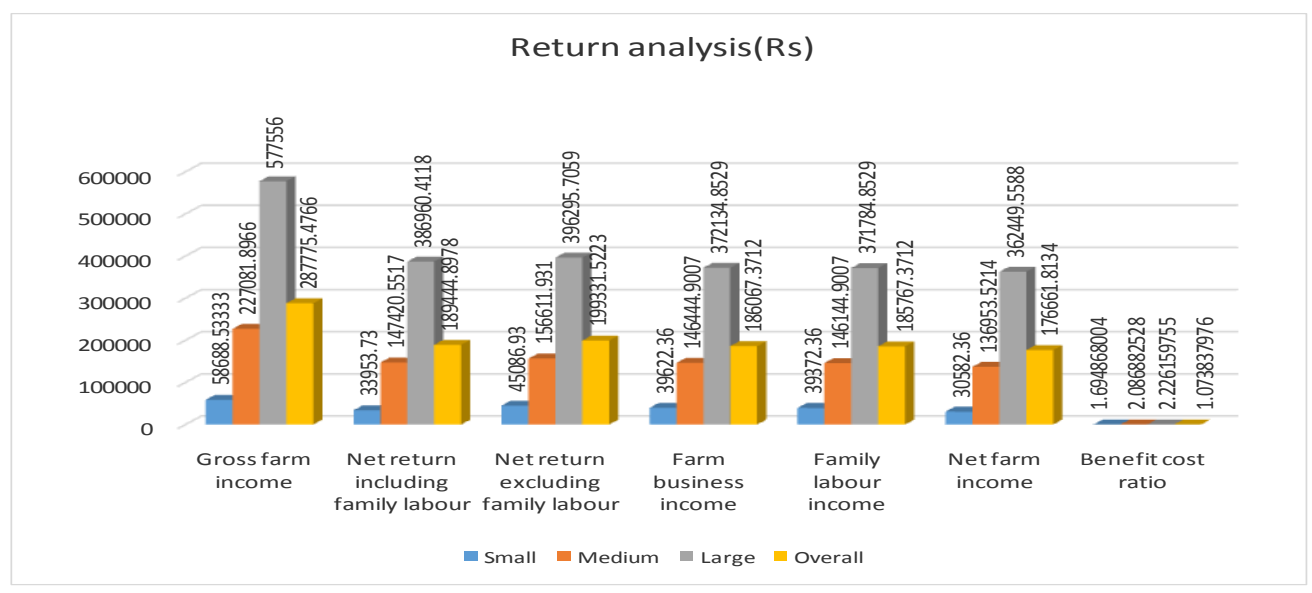

For the small farm category farm income was comparatively less as compared to medium and large farms. This is due to the fact that as farm size increases, returns also increases. Gross farm income was estimated to be Rs 58688.53/for small farms, Rs 227081.90/- for medium farms and Rs 577556.00/- for large farms. Net return also shows similar trend for the three categories where large farms obtain higher net returns as compared to other two categories. Net returns including family labour for the small, medium and large categories were Rs 33953.73/-, Rs 147420.60/- and Rs 386960.40/-, respectively. Net returns excluding family labour were estimated to be Rs 45086.96/-, Rs 156611.90/- and Rs 396295.70/- for small, medium and large farms, respectively.
Farm business income were estimated to be Rs 39622.36/-, Rs 146444.90/- and Rs 396295.70/for small, medium and large farms, respectively. The income from family labour for small, medium and large farms were Rs 39372.36/-, Rs 146144.90/- and Rs 371784.90/-, respectively. Net farm income for the small farm was estimated to be Rs 30582.36 and for medium and large farms it was Rs 136953.50/and Rs 362449.60/- respectively (Sharma, 2015) (Table 2).

The benefit cost ratio for small farms was comparatively less as compared to medium and large farms which were estimated to be 1.70 . The medium farms' benefit cost ratio was 2.09 and for the large farms it was 2.22. This 
suggests that large farms were performing better both in terms of production as well as efficiency. This may be due to input use efficiency in larger farms as compared to small farms. However, since the benefit cost ratio of all the three farm categories shows more than 1, therefore, it can be said that the respondents are benefitted from tea plantation. Similar findings was obtained by Saiwan for tea growers in Tripura where benefit cost ratio for small farm size farms was 2.10, which was lesser than larger sized farms (2.30)

Based the study conducted in the said area, some of the suggestions for the tea growers to overcome constraints and to enhance production viz; awareness on the availability of loans given by Tea Board for small tea growers should be made, trainings on knowledge regarding proper plucking of green leaf at the right time, method of pit digging and planting should be conducted by extension agents as most of the respondents were unaware of this, more farmers should be encouraged to take up tea plantation practice, and the existing farmers should be inspired to extend their plantation area and make use of available land by proper dissemination of information along with funding support as the study area was observed to be highly suitable for growing tea. The government should supply sapling materials in these areas so as to enable more farmers to take up tea plantation enterprise. This would significantly reduce the initial investment for starting up tea plantation. Vast area of virgin soil is available in the study area. So if the government would look into this matter and take serious steps in expanding tea plantation enterprise in the study area then it would not only help in improving the economy of the state but would also boost up tea production of India in general.

\section{References}

Choudhary, Ramjilal.; Rathore, D.S. and Sharma, Amod. 2017. An Economics Analysis of Production and Marketing of Groundnut in Porbandar District of Gujarat. Economic Affairs. 62(3). September: 547-553.

Sharma, A., Chauhan, S. Singh, A. K. Sharma, S. K. and Singh, S. P. 2000. Economics Of Milk Production on Different Farm Size Groups. Dairy Guide. XXI(3-4). July to December: 61-66.

Sharma, Amod. 2011. Economic and Constraints of King Chilli Growers in Dimapur District of Nagaland. Journal of Interacademicia. 15 (4): 710-719.

Sharma, Amod. 2015. Growth and Variability in area, Production and Yield of Cotton Crop. International Journal of Agriculture Innovations \& Research. 4(3). November: 509-511.

Sharma, Amod, Kichu, Yimkumba. and Chaturvedi, B. K. 2016. Economics and Constraints of Pineapple Cultivation in Dimapur District of Nagaland. The Journal of Rural and Agricultural Research. 16 (1). January: 72-75.

Vengoto, Venyo. and Sharma, Amod. 2018. Economic and Constraint of Potato crop in Kohima district of Nagaland. Technoframe. 7(1):75-80.

\section{How to cite this article:}

Imlibenla and Amod Sharma. 2019. Farm Efficiency Measure Analysis of Tea Plantation Crop in Mokokchung District of Nagaland. Int.J.Curr.Microbiol.App.Sci. 8(06): 1156-1163. doi: https://doi.org/10.20546/ijcmas.2019.806.143 